\title{
Harmonic Analysis in PV Connected Power System
}

\author{
Anita Gusai ${ }^{1}$, S. N. Joshi ${ }^{2}$ \\ ${ }^{1,2}$ Govt. Women Engineering College Ajmer, \\ India
}

\author{
K. G. Sharma ${ }^{3}$, N. K. Gupta ${ }^{4}$ \\ ${ }^{3,4}$ Engineering College Ajmer, \\ India
}

\begin{abstract}
In recent years it is shown in many researches that power quality problems in existing energy system are to be minimized for fulfillment of today's need of energy sector. In developing countries, per capita energy consumption is going to increase for upliftment of their living standards, and this increased per capita energy consumption can be met with incorporation of renewable energies in larger amount. Many of researchers have found their ways to incorporate renewable energies in existing energy sector worldwide, most of the renewable energy is utilized in energy sector as solar and wind. However, with incorporation of these renewable energy sources many power quality problems have also been introduced like as harmonic distortion, voltage sag and swell, interruption in current and voltages etc., and this affect the reliability of system. For better implementation of renewable energy sources in existing system, power quality problems are also to be reduced in the system. In this paper A PV system of $250 \mathrm{~kW}$ has been modeled and connected to existing grid system. Further the harmonic analysis with PV system connected grid has been carried out and harmonic filters has been designed which are connected in parallel with PV system and existing system. The modeling is done in MATLAB simulink.
\end{abstract}

Keywords- PV Array; IGBT Convertor; MPPT; Inverter control; filter

\section{INTRODUCTION}

Energy system is a primitive source which gives energy services to the customers. The energy system contains a consolidated arrangement of economical and technical systems that fulfill the energy demands. An energy demand is not a fixed amount; it varies accordance integrated set to price, consumption and regulation. Energy system is defined as production, conversion, delivery and use of energy into service such as establishment of grids, use of energy demand management including day lighting, solar building designing, respectively. For the most part, energy systems are adapted; to cut down the idea of non-inexhaustible assets, leak of hazardous substances and to minimize momentary cost of appropriate energy sources. The power generation from combined renewable source of energy makes power system more reliable and environment friendly. The demand of energy is increasing over last many years. Recently, diesel oil have highest cost or rate of pollution in environment due to fossil fuels behavior with exponentially decline in the cost of solar module become all the more encouraging source of electricity generation. Generally, photo voltaic system (PV) is considered as the components of energy generation systems [4].

The objective of this paper aims to analyze the impact of harmonic on $250 \mathrm{~kW}$ photovoltaic (PV) array with existing grid system. The PV system modelling and simulation is conducted using MATLAB Simulink software. In this results show that the proposed system gives AC power output by using solar PV system. Analyses are then carried out to investigate the impact of the PV system on AC current output. Based on the study, it is found that PV array installed at higher value of irradiance system produces more harmonic distortion in $\mathrm{AC}$ output current.

\section{PV SYSTEM}

PV system is basically a power system unit which it converts light energy into electrical energy by using semiconductor materials. A solar photovoltaic cell is an energy technology in which solar energy is convert into form of useful electricity by the process is called photovoltaic effect that generates voltage and current in PV cell when it is exposed in solar light. It is made of highly purified silicon material because silicon energy band gap $(1.12 \mathrm{eV})$ is approximately equal to photons energy band gap (1.6eV) [4]. The equivalent circuit of solar PV cell with one diode is depicted in fig 1.

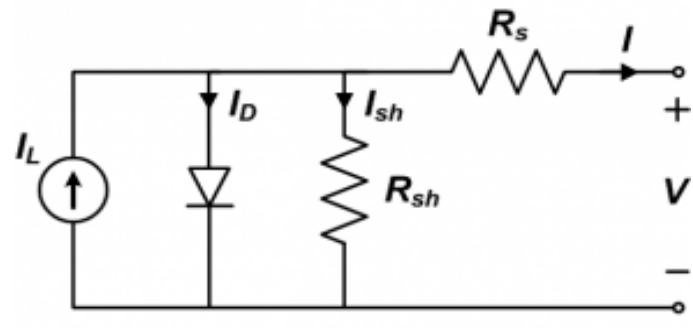

Fig.1 Equivalent circuit of one-diode model of PV cell

The load current I can be expressed in terms of output voltage $\mathrm{V}$ is given as:

$$
I=I_{L}-I_{0} *\left\{\exp \left(\frac{q}{n k T_{C}}\left(V+I_{S}\right)\right)-1\right\}-\frac{V+I_{S}}{R_{\text {sh }}}
$$

Where, $\mathrm{V}$ is Diode Voltage, $\mathrm{T}_{\mathrm{C}}$ is Cell Temperature $(\mathrm{K}), \mathrm{k}$ is Boltzmann Constant $\left(1.382 * 10^{-23} \mathrm{~J} / \mathrm{K}\right), \quad \mathrm{q}$ is Electron Charge $\left(1.062 * 10^{-19}{ }^{\circ} \mathrm{C}\right), \mathrm{I}_{\mathrm{L}}$ is Light Current, $\mathrm{I}_{\mathrm{O}}$ is Saturation Current, $\mathrm{R}_{\mathrm{S}}$ is Series Resistance, $\mathrm{R}_{\mathrm{sh}}$ is Shunt Resistance, $\mathrm{N}_{S}$ is Number of PV Cells Connected in Series.

In this thesis work of PV Array, we assume that day time from morning 6 AM -evening 6 PM. For particular time interval, the value of amplitude and temperature is varied. Amplitude is just an irradiance multiplying by thousand. The values of time intervals are given as below: 


\begin{tabular}{|c|c|c|c|c|c|c|c|}
\multicolumn{10}{c|}{ TABLE 1 Time Intervals } \\
\begin{tabular}{|c|c|c|c|c|c|} 
Time \\
Range
\end{tabular} & $\begin{array}{c}6 \\
\text { AM }\end{array}$ & $\begin{array}{c}8 \\
\text { AM }\end{array}$ & $\begin{array}{c}10 \\
\text { AM }\end{array}$ & $\begin{array}{c}12 \\
\text { PM }\end{array}$ & $\begin{array}{c}2 \\
\text { PM }\end{array}$ & $\begin{array}{c}4 \\
\text { PM }\end{array}$ & $\begin{array}{c}6 \\
\text { PM }\end{array}$ \\
\hline $\begin{array}{c}\text { Time } \\
\text { (sec) }\end{array}$ & 0 & 1.5 & 3 & 4.5 & 6 & 7.5 & 10 \\
\hline
\end{tabular}

solar radiation which is form to solar resource, is a general term for the electromagnetic radiation emitted by sun and these radiations can be captured and used in the form of energy i.e. heat and electricity. The amount of irradiance is responsible for hourly variation in sunlight. According to this table, in early morning 6AM, in all seasons relative to irradiance of the sun is low (0) in the sky and the lowest temperature is often recorded just after sunrise. Consequently, with each passing seconds, the sun emits more energy than early morning. Its ray travel further through the atmosphere than at Noon (12PM), sunlight is at its highest point of irradiance (1). The maximum temperature is recorded at noon. On a clear day, the maximum amount of solar energy is recorded around solar noon. At morning $(6 \mathrm{AM})$ and evening $(6 \mathrm{PM})$ solar radiation is passing through more of the atmosphere, which reduces its irradiance. Here, Irradiance $=$ Amplitude $(\mathrm{W} / \mathrm{m} 2)^{*} 1000$; the values of time, amplitude and temperature are given as below:

TABLE 2 Values of Time, Amplitude and Temperature

\begin{tabular}{|c|c|c|c|}
\hline $\begin{array}{c}\text { Time } \\
(\mathbf{s e c})\end{array}$ & Amplitude & $\begin{array}{c}\text { Irradiance } \\
(\mathbf{W} / \mathbf{m} 2)\end{array}$ & $\begin{array}{c}\text { Temperature } \\
\left({ }^{\circ} \mathbf{C}\right)\end{array}$ \\
\hline 0 & 0 & 0 & 20 \\
\hline 1.5 & 0.3 & 300 & 25 \\
\hline 3 & 0.6 & 600 & 30 \\
\hline 4.5 & 1 & 1000 & 35 \\
\hline 6 & 0.8 & 800 & 32 \\
\hline 7.5 & 0.6 & 600 & 28 \\
\hline 10 & 0 & 0 & 25 \\
\hline
\end{tabular}

\section{HARMONICS AND FILTER}

Power quality (PQ) problems of renewable energy sources are not new one; recently these problems have great impact on residential, commercial and industrial clients. Now a day, there is an increasing attention on power quality in electric power system. There are finite numbers of issues which influence the power quality of power system. Due to these, voltage and frequency are deviate from the rated values, which distort sinusoidal waveform and degrade the power quality. Harmonics distortion plays important role in power quality issues of power system. There are various issues like transients, voltage sag ,voltage swell, power frequency variations, current interruption in power system in which harmonics distortion is one of them Harmonics are defined as in term of the voltage and current having frequency which is integral multiple of fundamental frequency. These positive integer multiple of fundamental frequency generate distortion in output waveform i.e. not pure sinusoidal. Harmonics are termed as unwanted signals that present in the system because of non-linear load and causes voltage and current harmonics in the system.

Odd harmonics =multiples of odd integer in fundamental frequency such as $3,5,7,9,11$ etc.

Even harmonics $=$ multiples of even integer in fundamental frequency such as 2, 4, 6, 8 etc. Mostly, power system elements produce only odd harmonics. In solar PV system inverters are used to render and take power from grid and these are the sources of harmonics in PV plant. So, harmonics analyses in the power system are necessary to maintain system reliable and efficient [3].

Total harmonics distortion is measurement of harmonic distortion present in the waveform. Normally, there are two types of harmonic filters are used in the power system to mitigate harmonic distortion i.e. active harmonic filter (AHF) and passive harmonics filter (APF). To achieve acceptable distortion, reduce harmonics and improve power quality use shunt harmonic filter and connected in parallel which mitigate harmonics but practical passive filters are installed because of easy availability. In this work, to extract fundamental and harmonic distortions in current signals use FFT analysis. In many research works has done by using pulse width modulation (PWM) techniques for mitigate of harmonics [8].

\section{SIMULATION RESULT}

This system consists of $250 \mathrm{~kW}$ PV Array is connected to one power switching devices IGBT and Inverter control which consists of MPPT, PLL, PWM modulator, current regulator, DC voltage regulator etc. and converter is modeled using PWM controlled-IGBT bridge. A $250 / 25 \mathrm{kV}$ three phase transformer is used to connect inverter control to the utility distribution system. Simulation model for $250 \mathrm{~kW}$ PV array with filter disconnected is shown in fig. 2.

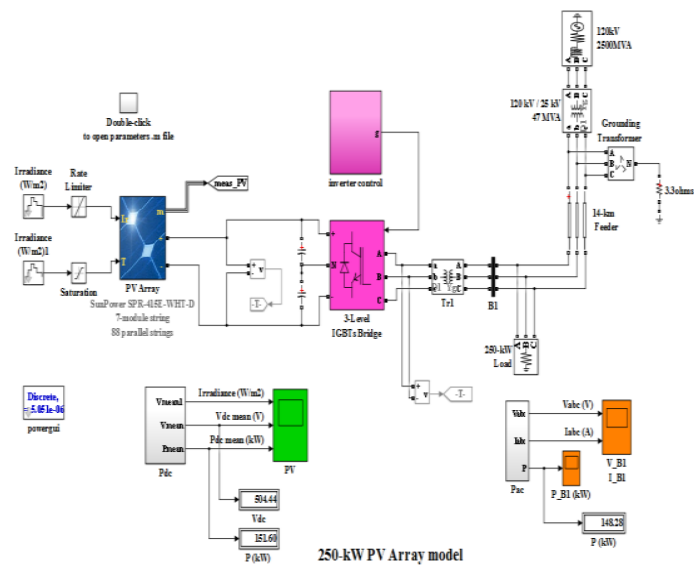

Fig. 2 Simulation model of 250kW PV System without filter

We assume that in last case at morning $6 \mathrm{AM}-$ evening 6

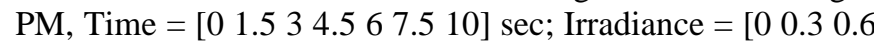
$10.80 .60]^{*} 1000 \mathrm{~W} / \mathrm{m} 2$; Temperature $=\left[\begin{array}{lll}20 & 2530353228\end{array}\right.$ $25]^{\circ} \mathrm{C}$; harmonic distortion is around $23.74 \%$. At Y-Axis in waveform, tick value for voltage $2.5^{*} 10^{4}$ is assume as 2.5 and so on. Output voltages, current and power waveform and harmonic analysis for all cases shown below in fig 3, 4, 5 and 6. 


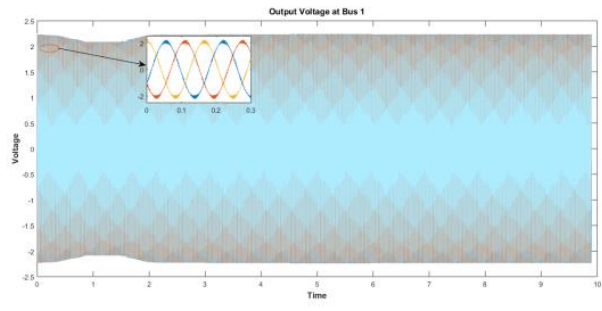

Fig. 3 Output Voltage Waveform of system with filter disconnected

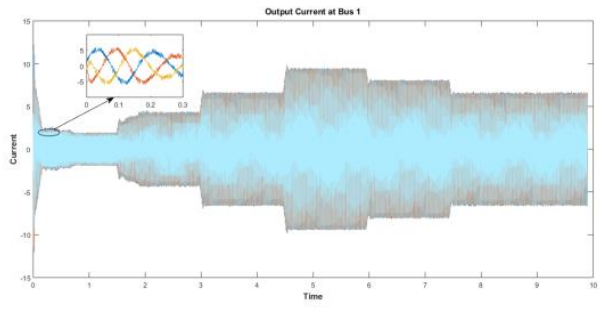

Fig. 4 Output Current Waveform of system with filter disconnected

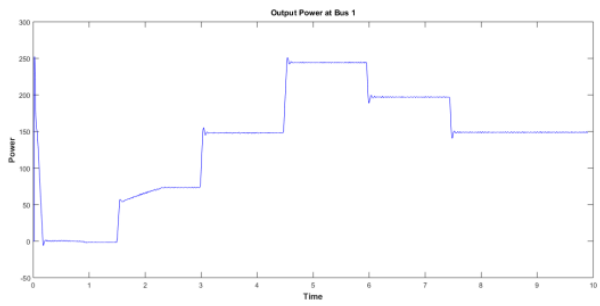

Fig. 5 Output Power Waveform of system with filter disconnected

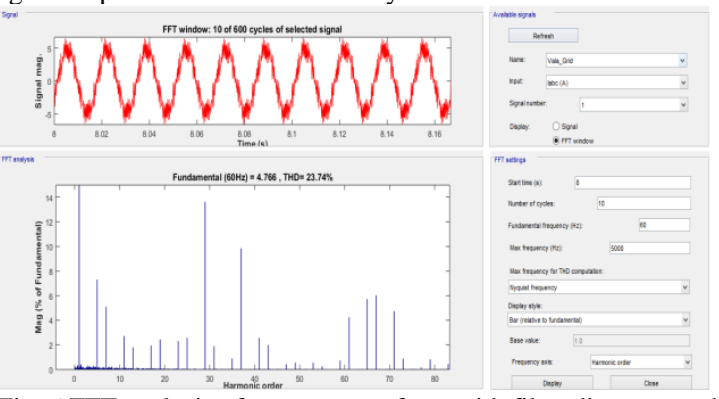

Fig. 6 FFT analysis of current waveform with filter disconnected

Harmonics distortion at bus current in PV array with filter disconnected in this case is $23.74 \%$. For all case studies of irradiance and temperature, output power, harmonic distortions at bus 1 are shown in table 3 .

TABLE 3 irradiance and temperature, output power, harmonic distortions without filter

\begin{tabular}{|c|c|c|c|c|c|}
\hline $\begin{array}{c}\text { Irradi } \\
\text { ance } \\
(\mathbf{W} / \mathbf{m} \\
\mathbf{2})\end{array}$ & $\begin{array}{c}\text { Temp } \\
\left({ }^{\mathbf{}} \mathbf{C}\right)\end{array}$ & $\begin{array}{c}\text { Bus } \\
\text { Voltage } \\
(\text { Volts) }\end{array}$ & $\begin{array}{c}\text { Bus } \\
\text { Current } \\
(\text { Amp) }\end{array}$ & $\begin{array}{c}\text { P Out } \\
\text { (watt) }\end{array}$ & $\begin{array}{c}\text { Harmonics } \\
\text { at Bus } \\
\text { Current } \\
(\%)\end{array}$ \\
\hline 0 & 20 & 2.085 & 2 & 0 & 1882.46 \\
\hline 300 & 25 & 2.227 & 4.3 & 73 & 48.72 \\
\hline 600 & 30 & 2.235 & 6.5 & 148 & 24.31 \\
\hline 1000 & 35 & 2.241 & 9 & 244 & 14.15 \\
\hline 800 & 32 & 2.235 & 8 & 197 & 18.90 \\
\hline 600 & 28 & 2.234 & 6.5 & 149 & 23.82 \\
\hline 0 & 25 & 2.088 & 1.8 & 0 & 1867.03 \\
\hline
\end{tabular}

In this $250 \mathrm{~kW}$ PV array with inverter choke RL and small filter $\mathrm{C}$ is used to diminish harmonics generated by IGBT inverter. Simulation model for $250 \mathrm{~kW}$ PV array filter connected is shown in fig. 7 .

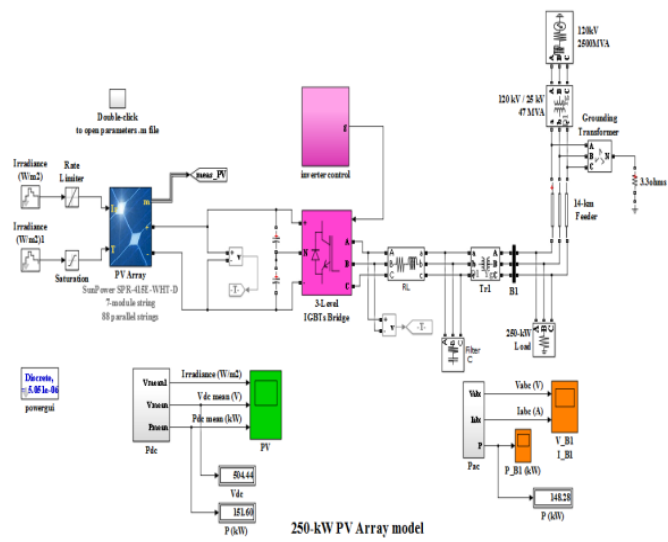

Fig. 7 Simulation model of 250kW PV System with filter

In these output waveforms, in all case voltage waveforms with filter connected are same but current is varied. For first case at $6 \mathrm{AM}$, for time range $=\left[\begin{array}{ll}0 & 10\end{array}\right] \mathrm{sec}$, Irradiance $=0$ $\mathrm{W} / \mathrm{m} 2$, Temperature is $20^{\circ} \mathrm{C}$ current is $0.3 \mathrm{amp}$, power output is near about $0 \mathrm{~kW}$ and because of low value of irradiance harmonic distortion is maximum around $191.06 \%$. In similar way, for second case at $8 \mathrm{AM}$, time range $=\left[\begin{array}{ll}0 & 10\end{array}\right] \mathrm{sec}$, Irradiance $=300 \mathrm{~W} / \mathrm{m} 2$, Temperature is $25^{\circ} \mathrm{C}$ for this current is $2.5 \mathrm{amp}$, power output is near about $73 \mathrm{~kW}$ and harmonic distortion is around $5.76 \%$. Similarly, for third case at 10 $\mathrm{AM}$, time range $=\left[\begin{array}{ll}0 & 10\end{array}\right] \mathrm{sec}$, Irradiance $=600 \mathrm{~W} / \mathrm{m} 2$, Temperature is $30^{\circ} \mathrm{C}$ for this current is $4.8 \mathrm{amp}$, power output is near about $148 \mathrm{~kW}$ and harmonic distortion is around $2.14 \%$. Similarly, in forth case at noon $12 \mathrm{PM}$, time range $=$ $\left[\begin{array}{ll}0 & 10\end{array}\right] \mathrm{sec}$, Irradiance $=1000 \mathrm{~W} / \mathrm{m} 2$, Temperature is $35^{\circ} \mathrm{C}$ for this current is $8 \mathrm{amp}$, power output is near about $245 \mathrm{~kW}$ and because of maximum value of irradiance harmonic distortion is minimum around $1.52 \%$. Similarly, for fifth case at $2 \mathrm{PM}$, time range $=\left[\begin{array}{ll}0 & 10\end{array}\right] \mathrm{sec}$, Irradiance $=800 \mathrm{~W} / \mathrm{m} 2$, Temperature is $32^{\circ} \mathrm{C}$ for this current is $6.4 \mathrm{amp}$, power output is near about $197 \mathrm{~kW}$ and harmonic distortion is around $1.90 \%$. Similarly, for sixth case at $10 \mathrm{AM}$, time range $=\left[\begin{array}{ll}0 & 10\end{array}\right] \mathrm{sec}$, Irradiance $=$ $600 \mathrm{~W} / \mathrm{m} 2$, Temperature is $28^{\circ} \mathrm{C}$ for this current is $4.9 \mathrm{amp}$, power output is near about $149 \mathrm{~kW}$ and harmonic distortion is around $2.30 \%$. Similarly, for seventh case at $6 \mathrm{PM}$, time range $=\left[\begin{array}{ll}0 & 10\end{array}\right] \mathrm{sec}$, Irradiance $=0 \mathrm{~W} / \mathrm{m} 2$, Temperature is $25^{\circ} \mathrm{C}$ for this current is $0.3 \mathrm{amp}$, power output is nearly $0 \mathrm{~kW}$ and harmonic distortion is around $191.31 \%$. Output voltages, current and power waveforms of all cases shown below in fig. 8, 9, 10, and 11 .

We assume that in last case at morning $6 \mathrm{AM}-$ evening 6 $\mathrm{PM}$, Time $=\left[\begin{array}{llllll}0 & 1.5 & 3 & 4.5 & 6 & 7.5\end{array}\right] \mathrm{sec}$; Irradiance $=\left[\begin{array}{lll}0 & 0.3 & 0.6\end{array}\right.$ $10.80 .60]^{*} 1000 \mathrm{~W} / \mathrm{m} 2$; Temperature $=\left[\begin{array}{llll}20 & 25303532 & 28\end{array}\right.$ $25{ }^{\circ} \mathrm{C}$; harmonic distortion is around $2.33 \%$. At $\mathrm{Y}$-Axis in waveform, tick value for voltage $2.5^{*} 10^{4}$ is assumed as 2.5 and so on.

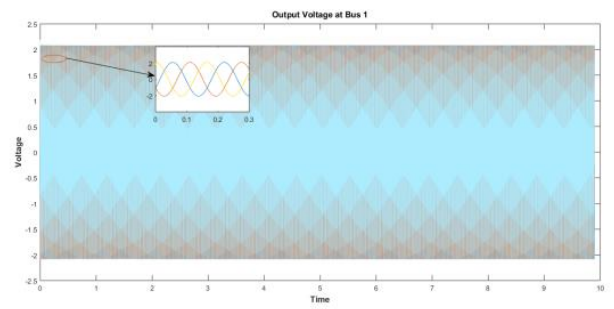

Fig.8 Output Voltage Waveform of system with filter connected 


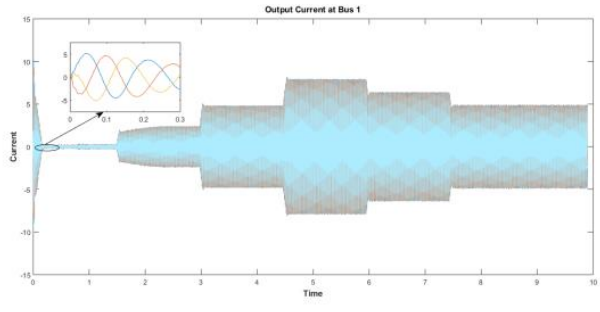

Fig. 9 Output Current Waveform of system with filter connected

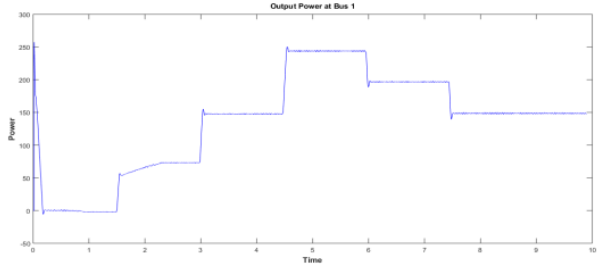

Fig. 10 Output Power Waveform of system with filter connected

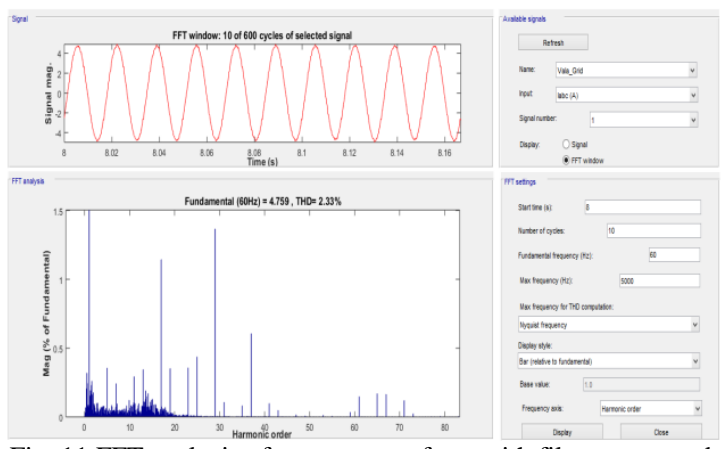

Fig. 11 FFT analysis of current waveform with filter connected.

Harmonics distortion at bus current in PV array with filter connected in this case is $2.33 \%$. For all case studies of irradiance and temperature, output power, harmonic distortions at bus 1 are shown in table 4 .

TABLE 4. Irradiance and Temperature, Output Power, Harmonic Distortions with Filter

\begin{tabular}{|c|c|c|c|c|c|}
\hline $\begin{array}{c}\text { Irradi } \\
\text { ance } \\
(\mathbf{W} / \mathbf{m} \\
\mathbf{2})\end{array}$ & $\begin{array}{c}\text { Temp } \\
\left({ }^{\circ} \mathbf{C}\right)\end{array}$ & $\begin{array}{c}\text { Bus } \\
\text { Voltage } \\
(\text { Volts) }\end{array}$ & $\begin{array}{c}\text { Bus } \\
\text { Current } \\
(\text { Amp) }\end{array}$ & $\begin{array}{c}\text { P Out } \\
\text { (watt) }\end{array}$ & $\begin{array}{c}\text { Harmonics } \\
\text { at Bus } \\
\text { Current } \\
(\%)\end{array}$ \\
\hline 0 & 20 & 2.079 & 0.3 & 0 & 191.06 \\
\hline 300 & 25 & 2.082 & 2.5 & 73 & 5.76 \\
\hline 600 & 30 & 2.0835 & 4.8 & 148 & 2.14 \\
\hline 1000 & 35 & 2.085 & 8 & 245 & 1.52 \\
\hline 800 & 32 & 2.084 & 6.4 & 197 & 1.90 \\
\hline 600 & 28 & 2.083 & 4.9 & 149 & 2.30 \\
\hline 0 & 25 & 2.079 & 0.3 & 0 & 191.31 \\
\hline
\end{tabular}

Parameters of PV array used in this system are shown below in table 5 .

TABLE 5 Parameters of PV Array

\begin{tabular}{|c|c|}
\hline Different parameters & Ratings \\
\hline Nominal power $(\mathrm{P})$ & $250 \mathrm{e} 3$ \\
\hline Open circuit voltage $\left(\mathrm{V}_{\mathrm{OC}}\right)$ & $85.3 \mathrm{~V}$ \\
\hline Short-circuit current $\left(\mathrm{I}_{\mathrm{SC}}\right)$ & $6.09 \mathrm{~A}$ \\
\hline $\begin{array}{c}\text { Diode saturation } \\
\text { current }\left(\mathrm{I}_{\mathrm{O}}\right)\end{array}$ & $7.1712 \mathrm{e}-13 \mathrm{~A}$ \\
\hline $\begin{array}{c}\text { Shunt resistance }\left(\mathrm{R}_{\mathrm{sh}}\right) \\
\text { Series resistance }\left(\mathrm{R}_{\mathrm{S}}\right)\end{array}$ & $419.78 \mathrm{ohms}$ \\
\hline
\end{tabular}

\section{CONCLUSION}

The modeling of $250 \mathrm{~kW}$ PV system has been done in MATLAB simulink. The PV system is connected to existing grid and harmonic spectrum has been analyzed from FFT analysis. Further a harmonic filter is connected to the PV connected existing grid and again harmonic spectrum has been taken. From the results it has been shown that total harmonic distortion has been significantly reduced to the level of $2.3 \%$. The study has been done for a typical day where different levels of solar radiation and temperatures have been taken.

This study can be implemented further in real power system implementation in larger scale.

\section{REFERENCES}

[1] Kaveh Rahimi, Saeed Mohajeryami, Alireza Majzoobi, "Effects of Photovoltaic Systems on Power Quality", North American Power Symposium, IEEE, September 2016

[2] Dinesh Kumar, Firuz Zare, "Harmonic Analysis of Grid Connected Power Electronic Systems in Low Voltage Distribution Networks", Journal of Emerging and Selected Topics in Power Electronics, IEEE, vol. 4, no. 70 - 79, July 2015

[3] An LUO, Qianming XU, Fujun MA, Yandong CHEN, "Overview of power quality analysis and control technology for the smart grid", Journal of Modern Power Systems and Clean Energy, Vol. 4, no. 1-9, January 2016

[4] Rinchin W. Mosobi, Toko Chichi and Sarsing Gao, "Power quality analysis of hybrid renewable energy System", Cogen Engineering, vol. 2, January 2015

[5] Sarita Samal and Prakash Kumar Hota, "Design and analysis of solar PV-fuel cell and wind energy based microgrid system for power quality improvement", Cogent Engineering, vol. 4, no. 121, November 2017

[6] George Serițan, Ion Tristiu, Oana Ceaki, Tudor Boboc, "Power Quality Assessment for Microgrid Scenarios", International Conference and Exposition on Electrical and Power Engineering, October 2016

[7] H.Yousef, A.H.Al-Badi, A.Polycarpou, "Power management for hybrid distributed generation systems", International Journal of Sustainable Engineering, vol. 11, no. 65-74, Oct 2017

[8] Sufyanu A, "Power Quality and Harmonic Analysis in Three Phase Systems", Journal of Electrical \& Electronic Systems, vol. 7, no. 1-7, Dec 2018

[9] Rashid Al Badwawi, Mohammad Abusara, Tapas Mallick, "A Review of Hybrid Solar PV and Wind Energy System”, Smart Science, vol. 3, no. 127-138, Jan 2016

[10] Rajiv K. Varma, Shah Arifur Rahman, Tim Vanderheide, Michael D. N. Dang, "Harmonic Impact of a 20-MW PV Solar Farm on Utility Distribution Network", IEEE Power and Energy Technology Systems Journal, vol. 3, no. 89 - 98, September 2016

[11] Ranjbaran, M. Ebadian "A power sharing scheme for voltage unbalance and harmonics compensation in an islanded microgrid”, Electric Power Systems Research, Elsevier, vol. 155 no. 153-163, September 2017

[12] Tripti Gupta and Swapnil Namekar "Harmonic Analysis and Suppression in Hybrid Wind \& PV Solar System" Internationa Conference on Electrical, Electronics, Materials and Applied Science, april 2018 